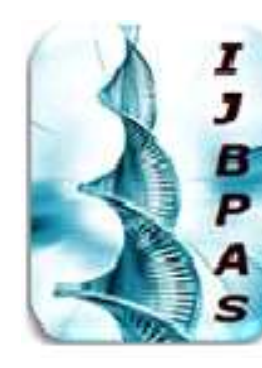

International Journal of Bhology, Pharmacy and Allied Seiences (IJBPAS)

'A Bridge Botuen Cabortory and Q andor'

Www.iibpas.com

\title{
METHOD DEVELOPMENT, VALIDATION AND FORCED DEGRADATION STUDIES OF RITONAVIR, AN ANTI-RETROVIRAL DRUG USING REVERSE PHASE-HIGH PERFORMANCE LIQUID CHROMATOGRAPHY
}

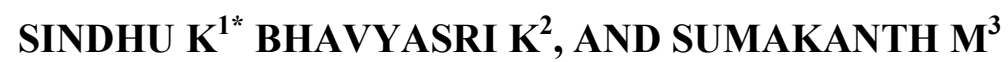

1,2,3 Department of Pharmaceutical Analysis, RBVRR Women's College of Pharmacy, Barkatpura, Hyderabad-500007

Received 28 ${ }^{\text {th }}$ Oct. 2019; Revised $20^{\text {th }}$ Nov. 2019; Accepted $29^{\text {th }}$ Dec. 2019; Available online $1^{\text {st }}$ May 2020

https://doi.org/10.31032/IJBPAS/2020/9.5.5054

*Corresponding Author: E Mail: bhavya.khagga@gmail.com

\begin{abstract}
A simple, precise, accurate method was developed for the estimation of Ritonavir by RP-HPLC technique. Chromatographic conditions used are stationary phase Ascentis C18 150mm x 4.6 $\mathrm{mm}, 2.7 \mu$, Mobile phase Acetonitrile: $\mathrm{NaH}_{2} \mathrm{PO}_{4}$ in the ratio of $60: 40$. Then $\mathrm{pH}$ adjusted to 4 with orthophosphoric acidand flow rate was maintained at $1 \mathrm{ml} / \mathrm{min}$, detection wave length was $239 \mathrm{~nm}$, column temperature was set to $30^{\circ} \mathrm{C}$ and diluent was mobile phase. Conditions were finalized as optimized method. System suitability parameters were studied by injecting the standard six times and results were well under the acceptance criteria. Linearity study was carried out between $25 \%$ to $150 \%$ levels, $\mathrm{R}^{2}$ value was found to be as 0.999 . Precision was found to be 0.3 for repeatability and 0.7 for intermediate precision. LOD and LOQ are $0.54 \mu \mathrm{g} / \mathrm{ml}$ and $1.65 \mu \mathrm{g} / \mathrm{ml}$ respectively. By using above method assay of marketed formulation was carried out $99.49 \%$ was present. Degradation studies of Ritonavir were done, in all conditions purity threshold was more than purity angle and within the acceptable range.
\end{abstract}

Keywords: Degradation; HPLC; ICH Guidelines; Ritonavir; Validation parameters 


\section{INTRODUCTION}

Ritonavir is an antiretroviral drug from the protease inhibitor class used to treat HIV infection and AIDS. Ritonavir is frequently prescribed with Highly Active AntiRetroviral Therapy, not for its antiretroviral action, but as it inhibits the same host enzyme that metabolizes other protease inhibitors. This inhibition leads to higher plasma concentrations of these latter drugs, allowing the clinician to lower their dose and frequency and improving their clinical efficacy. It has the structural formula and shown in (Figure 1). The chemical name of Ritonavir is $(5 \mathrm{~S}, 8 \mathrm{~S}, 10 \mathrm{~S}, 11 \mathrm{~S})-10-$ hydroxy- 2- methyl- 5- (1-methylethyl)-1- [2(1- methylethyl) - 4- thiazolyl]- 3, 6- dioxo8, 11- bis (phenylmethyl)-2, 4, 7, 12etraazatridecan-13oic acid 5-thiazolyl methyl ester. It is official in Indian Pharmacopoeia (Indian Pharmacopoeia, vol. III, 2007, 1058) [6] and United States Pharmacopoeia (United States Pharmacopoeia 30, National Formulary 25, 2007, 3143) [14].

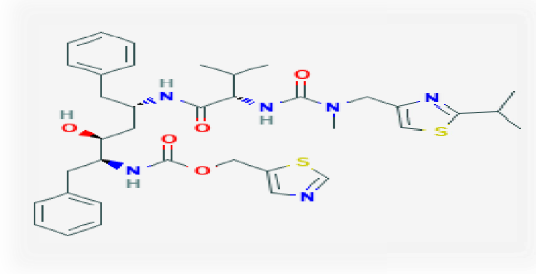

Figure 1: Structure of Ritonavir Ritonavir is an HIV protease inhibitor that interferes with the reproductive cycle of HIV.
Although it was initially developed as an independent antiviral agent, it has been shown to possess advantageous properties in combination regimens with low-dose ritonavir and other protease inhibitors. It is now more commonly used as a booster of other protease inhibitors and is available in both liquid formulation and as capsules. While ritonavir is not an active antiviral agent against hepatitis $\mathrm{C}$ virus (HCV) infection, it is added in combination therapies indicated for treatment of $\mathrm{HCV}$ infections as a booster [1-8].

Ritonavir is a potent CYP3A inhibitor that increases peak and trough plasma drug concentrations of other protease inhibitors such as Paritaprevir and overall drug exposure. American Association for the Study of Liver Diseases (AASLD) and the Infectious Diseases Society of America (IDSA) guidelines recommend ritonavirboosted combination therapies as a first-line therapy for $\mathrm{HCV}$ Genotype $1 \mathrm{a} / \mathrm{b}$ and 4 treatment-naïve patients with or without cirrhosis [9-13].

Ritonavir is found in a fixed-dose combination product with Ombitasvir, Dasab uvir, and Paritaprevir as the FDA-approved product Viekira Pak. First approved in December 2014, Viekira Pak is indicated for 
the treatment of $\mathrm{HCV}$ genotype $1 \mathrm{~b}$ without cirrhosis or with compensated cirrhosis, and when combined with Ribavirin for the treatment of $\mathrm{HCV}$ genotype 1a without cirrhosis or with compensated cirrhosis.

From the literature survey, it was found that Ritonavir estimated by analytical methods such as reversed-phase high-performance liquid chromatographic (RP-HPLC) method [10] LC-MS [13] and HPTLC method [12]. The developed method was simple, precise, specific and accurate. The statistical analysis proved that method is reproducible and selective for the analysis of Ritonavir in bulk drug and tablet formulations [14-17].

\section{MATERIALS AND INSTRUMENTS}

1.HPLC instrument used was of WATERS HPLC 2965 SYSTEM with Auto Injector and PDA Detector. Software used is Empower 2. UV-VIS spectrophotometer PG Instruments T60 with special bandwidth of $2 \mathrm{~mm}$ and $10 \mathrm{~mm}$ and matched quartz was be used for measuring absorbance for Ritonavir solutions.

2.Sonicator (Ultrasonic sonicator)

3. $\mathrm{P}^{\mathrm{H}}$ meter (Thermo scientific)

4.Micro balance (Sartorius)

5.Vacuum filter pump

\section{Reagents used:}

1.Methanol HPLC Grade (RANKEM)

2.Acetonitrile HPLC Grade (RANKEM)

3.HPLC grade Water (RANKEM)

4.Glacial Acetic acid

The optimized chromatographic conditions are summarized in Table $\mathbf{1}$.

Table 1: Optimized chromatographic conditions for the proposed method

\begin{tabular}{|c|c|}
\hline Parameters & Optimized condition \\
\hline Column & Ascentis C18 150 $\times 4.6 \mathrm{~mm}, 5 \mu$ \\
\hline Mobile phase & Acetonitrile $: 0.01 \mathrm{~N} \mathrm{NaH} \mathbf{P O}_{4}(60: 40)$ \\
\hline Flow rate & $1.0 \mathrm{ml} / \mathbf{m i n}$ \\
\hline Detector & PDA 239nm \\
\hline Temperature & $30^{0} \mathrm{C}$ \\
\hline Injection Volume & $5.0 \mu \mathrm{L}$ \\
\hline Pump mode & Isocratic \\
\hline Run time & $10 \mathrm{~min}$ \\
\hline
\end{tabular}

Selection of diluent: Based up on the solubility of the drugs, diluent was selected, Acetonitrile and $0.01 \mathrm{~N} \mathrm{NaH} \mathrm{PO}_{4}$ Buffer in the ratio of 60:40.

Preparation of standard stock solutions: Accurately weighed $25 \mathrm{mg}$ of Ritonavir transferred into a $25 \mathrm{ml}$ volumetric flask, 3/4th of diluents was added and sonicated for 10 minutes. Flasks were made up with diluents and labeled as Standard stock solution $(1000 \mu \mathrm{g} / \mathrm{ml}$ of Ritonavir).

Preparation of standard working solutions (100\% solution): $1 \mathrm{ml}$ of Ritonavir from stock solution was pipetted out and taken into 
a $10 \mathrm{ml}$ volumetric flask and made up with diluent. (100 $\mathrm{g} / \mathrm{ml}$ of Ritonavir).

Preparation of Sample stock solutions: 10 tablets were weighed and the average weight of each tablet was calculated, then the weight equivalent to 1 tablet was transferred into a $25 \mathrm{ml}$ volumetric flask, add $10 \mathrm{ml}$ of diluent and shake to mix well and then make up with the diluent and sonicated for $25 \mathrm{~min}$, and filtered by HPLC filters $(1000 \mu \mathrm{g} / \mathrm{ml}$ of Ritonavir).

\section{Preparation of Sample working solutions} (100\% solution): $1 \mathrm{ml}$ of filtered sample stock solution was transferred to $10 \mathrm{ml}$ volumetric flask and made up with diluent. $(100 \mu \mathrm{g} / \mathrm{ml}$ of Ritonavir)

\section{Preparation of buffer:}

0.01N $\mathrm{NaH}_{2} \mathrm{PO}_{4}$ Buffer: Accurately weighed $1.41 \mathrm{gm}$ of Sodium dihyrogen Ortho phosphate in a $1000 \mathrm{ml}$ of Volumetric flask add about $900 \mathrm{ml}$ of HPLC grade water added and degas to sonicate and finally make up the volume with water then $\mathrm{pH}$ adjusted to 4 with dil. Orthophosphoric acid solution.

\section{Preparation of Calibration Curve:}

From the standard stock solution, the various dilutions of Ritonavir in the concentration of $25,50,75,100,125$ and $150 \mu \mathrm{g} / \mathrm{ml}$ were prepared. The solutions were injected using a $20 \mu$ fixed loop in to the chromatographic system at the flow rate of $1.0 \mathrm{ml} / \mathrm{min}$ and the effluents were monitored at $239 \mathrm{~nm}$, chromatograms were recorded. The Ritonavir was eluted at $2.41 \mathrm{~min}$ as shown in (Figure 2). The calibration curve was constructed by plotting average peak area versus concentration and was presented in (Figure 3). The method was extended for determination of Ritonavir in pharmaceutical dosage form containing $100 \quad \mathrm{mg}$ (EMPETUS). The proposed methods were validated as per the ICH guidelines (ICH Procedures Q2A, 1994) [3].

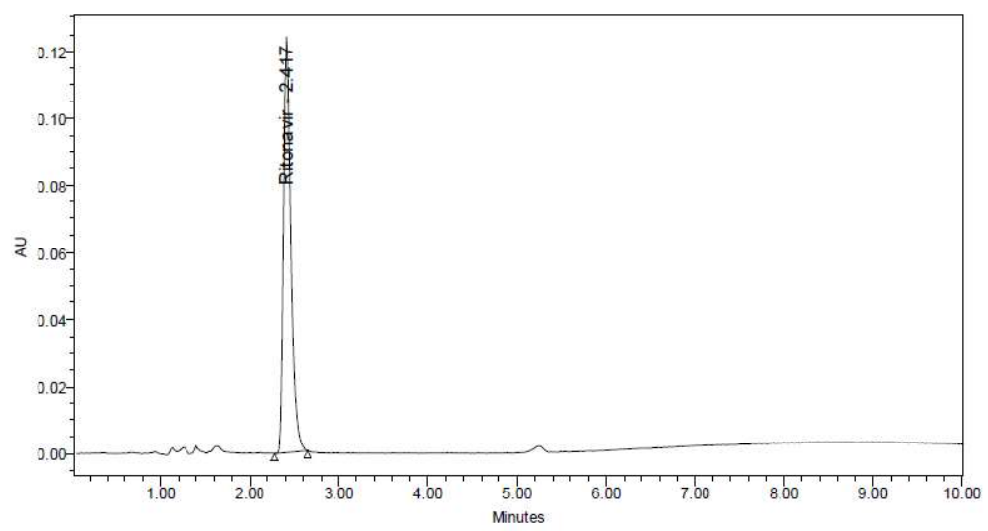

Figure 2: Typical Rp-Hplc chromatogram of Ritonavir 


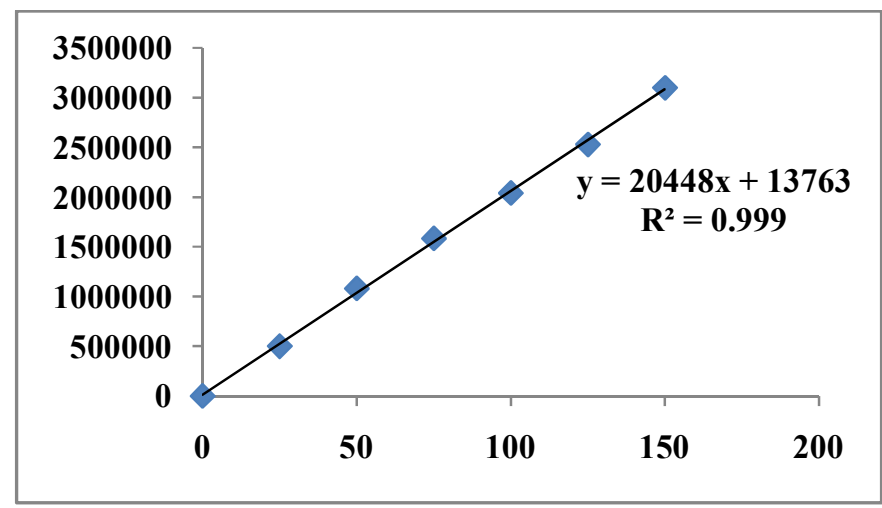

Figure 3: Calibration Curve of Ritonavir

\section{ASSAY}

Assay of the marketed formulation was carried out by injecting sample corresponding to equivalent weight into HPLC system. And percent purity was found out by following formulae. Calculate the percentage purity of Ritonavir present in tablet using the formula:

\section{Calculation:}

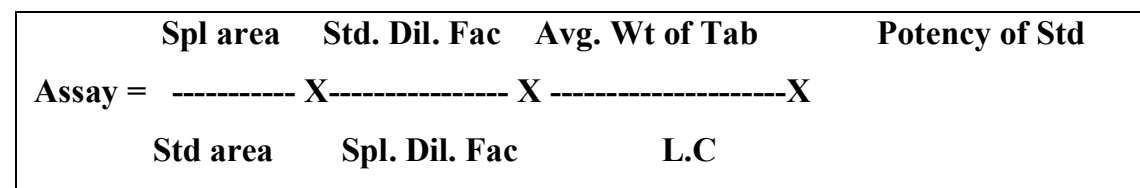

Spl area - Sample Peak area

Std area - Standard Peak area

Std. Dil. Fac- standard dilution factor

Spl. Dil. Fac- sample dilution factor

Avg. Wt of Tab- average weight of tablet

L.C - label claim

Potency of Standard

\section{DEGRADATION STUDIES}

To $1 \mathrm{ml}$ of stock solution of Ritonavir $1 \mathrm{ml}$ of $20 \%$ hydrogen peroxide $\left(\mathrm{H}_{2} \mathrm{O}_{2}\right)$ wasadded. The solutions were kept for 30 min at $60^{\circ} \mathrm{C}$. For HPLC study, the resultant solution was diluted using methanol to obtain $(100 \mu \mathrm{g} / \mathrm{ml})$ solution and $10.0 \mu \mathrm{l}$ were injected into the system and the chromatograms were recorded to assess the stability of sample.

\section{Oxidation:}

\section{Acid Degradation Studies:}

To $1 \mathrm{ml}$ of stock solution of Ritonavir, $1 \mathrm{ml}$ of $1 \mathrm{~N}$ Hydrochloricacidwasadded and refluxed for $30 \mathrm{mins}$ at $60^{\circ} \mathrm{C}$. Then neutralize the solution with $1 \mathrm{ml}$ of $1 \mathrm{~N}$ sodium hydroxide solution and the resultant solution was diluted using methanol as diluents to obtain $(100 \mu \mathrm{g} / \mathrm{ml})$ solution and $10.0 \mu 1$ solutions were injected into the 
system and the chromatograms were recorded to assess the stability of sample.

\section{Alkali Degradation Studies:}

To $1 \mathrm{ml}$ of stock solution of Ritonavir, $1 \mathrm{ml}$ of $1 \mathrm{~N}$ sodium hydroxide was added and refluxed for $30 \mathrm{mins}$ at $60^{\circ} \mathrm{C}$. Then neutralize the solution with $1 \mathrm{ml}$ of $1 \mathrm{~N}$ Hydrochloricacid solution and the resultant solution was diluted using methanol as diluentto obtain $(100 \mu \mathrm{g} / \mathrm{ml})$ solution and $10.0 \mu 1$ were injected into the system and the chromatograms were recorded to assess the stability of sample.

\section{Thermal Degradation Studies:}

The standard drug powder was placed in hot

\section{RESULTS AND DISCUSSION}

A system suitability test was applied to representative chromatograms for various parameters. The results obtained were within acceptable limits and are represented in Table 2.

Thus, the system meets suitable criteria. The calibration curve was obtained for a series of concentration in the range of $50-150 \mu \mathrm{g} / \mathrm{ml}$ and it was found to be linear. The data of regression analysis of the calibration curves are shown in Table 3.

\section{Precision:}

Repeatability: Six working sample solutions of $40 \mathrm{ppm}$ are injected and the \% Amount found was calculated and \% RSD was found air oven at $75^{\circ} \mathrm{C}$ for 24 hrs. For HPLC study,the standard solution was prepared using methanol as diluent and diluted to $(100 \mu \mathrm{g} / \mathrm{ml})$ solution and $10.0 \mu \mathrm{l}$ were injected into the system and the chromatograms were recorded to assess the stability of the sample.

\section{Photo Stability Studies:}

The standard drug was taken in a petriplate and exposed to sunlight for $24 \mathrm{hrs}$. For HPLC study, the standard solution was prepared using methanol as diluentto obtain $(100 \mu \mathrm{g} / \mathrm{ml})$ solution and $10.0 \mu 1$ were injected into the system and the chromatograms were recorded to assess the stability of sample. to be 0.3 and chromatogram was shown in Figure 5.

\section{Intermediate precision:}

Five working sample solutions of $40 \mathrm{ppm}$ are injected on the next day of the preparation of sample and the \% Amount found was calculated and \%RSD was found to be 0.7 and chromatogram was shown in Figure 6.

\section{Linearity:}

To demonstrate the linearity of assay method, inject 6 standard solutions with concentrations of about $25 \mathrm{ppm}$ to $150 \mathrm{ppm}$ of Ritonavir. Plot a graph to concentration versus peak area. Slope obtained was 20448 Y-Intercept was 13763 and Correlation Co- 
efficient was found to be 0.999 and Linearity plot was shown in Figure 3.

Robustness: Small Deliberate change in the method are made like Flow minus, flow plus, Mobile

phase minus, Mobile phase plus, Temperature minus, Temperature Plus. $\%$ RSD of the above conditions are calculated Figure 7.

Accuracy: Three Concentrations of $50 \%$, $100 \%, 150 \%$ are Injected in a triplicate manner and \% Recovery was calculated as 99.47 (Table 7).

\section{Assay of marketed formulation :}

Standard solution and sample solution were injected separately into the system and chromatograms were recorded and drug present in sample was calculated using before mentioned formula (Table 8).

Degradation studies:
Degradation studies were performed with the formulation and the degraded samples were injected.

Assay of the injected samples was calculated and all the samples passed the limits of degradation (Table 9).

The precision was measured in terms of repeatability, which was determined by sufficient number of aliquots of a homogenous sample. The \% RSD was found and lying with in 2. This showed that the precision of the method was satisfactory. The accuracy of the method was inferred by establishing the precision and linearity studies of the standard. The \% RSD was less than 2.0. Ruggedness and Robustness were determined and the \% RSD values were calculated. Limit of detection (LOD) and Limit of quantitation (LOQ) were determined. The results of validation parameters are summarized in Table $\mathbf{1 0 .}$

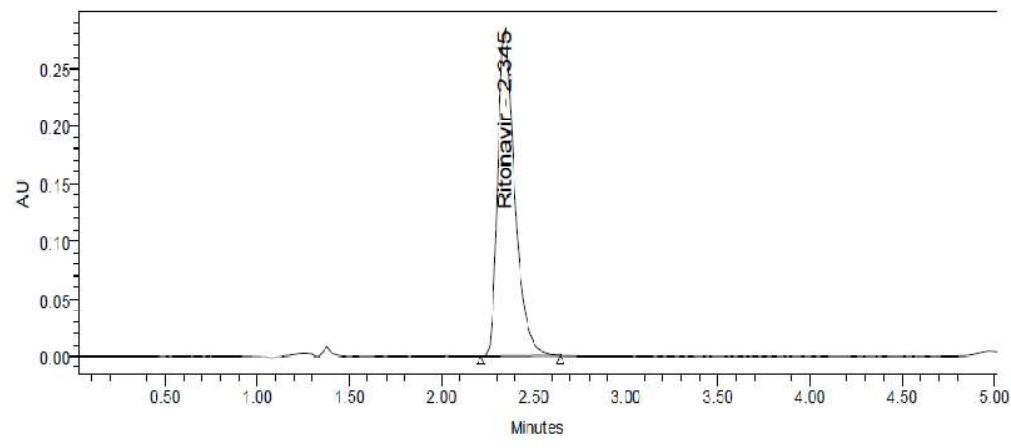

Figure 4: System suitability Chromatogram 
Table 2: System Suitability test parameters for the proposed method

\begin{tabular}{|c|c|}
\hline Parameters & Values \\
\hline Theoretical Plates & 1.41 \\
\hline Tailing factor & $\mathbf{3 0 9 7 . 6 6}$ \\
\hline Retention Time & 2.41 \\
\hline
\end{tabular}

Table 3: Regression analysis of the calibration curve for the proposed method

\begin{tabular}{|c|c|}
\hline Parameters & Values \\
\hline Linearity Range $(\boldsymbol{\mu g} / \mathbf{m l})$ & $\mathbf{2 5 - 1 5 0}$ \\
\hline Correlation coefficient $\left(\mathbf{r}^{2}\right)$ & $\mathbf{0 . 9 9 9}$ \\
\hline Regression equation & $\mathbf{y}=\mathbf{2 0 4 4 8 x}+\mathbf{1 3 7 6 3}$ \\
\hline Intercept & $\mathbf{1 3 7 6 3}$ \\
\hline Slope & $\mathbf{2 0 4 4 8}$ \\
\hline
\end{tabular}

Table 4: Repeatability data

\begin{tabular}{|c|c|}
\hline S.No & Peak Area \\
\hline 1 & 2050319 \\
\hline 2 & 2041976 \\
\hline 3 & 2055454 \\
\hline 4 & 2047756 \\
\hline 5 & 2054109 \\
\hline 6 & 2043173 \\
\hline AVG & 2048798 \\
\hline STDEV & 5551.4 \\
\hline \%RSD & 0.3 \\
\hline
\end{tabular}

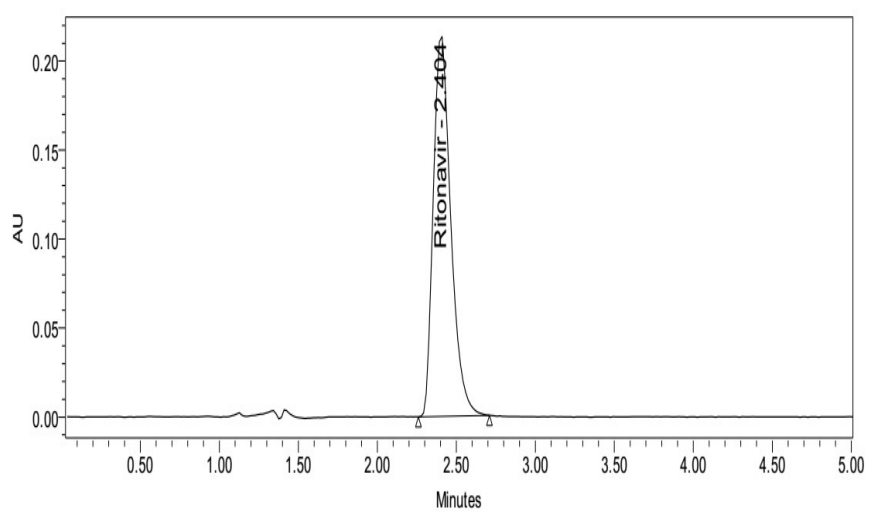

Figure 5: Repeatability Chromatogram

Table 5: Intermediate precision data

\begin{tabular}{|c|c|}
\hline S.No & Peak Area \\
\hline 1 & 1900261 \\
\hline 2 & 1889657 \\
\hline 3 & 1869317 \\
\hline 4 & 1892620 \\
\hline 5 & 1902289 \\
\hline AVG & 1901495 \\
\hline STDEV & 1892607 \\
\hline \%RSD & 12509.6 \\
\hline
\end{tabular}




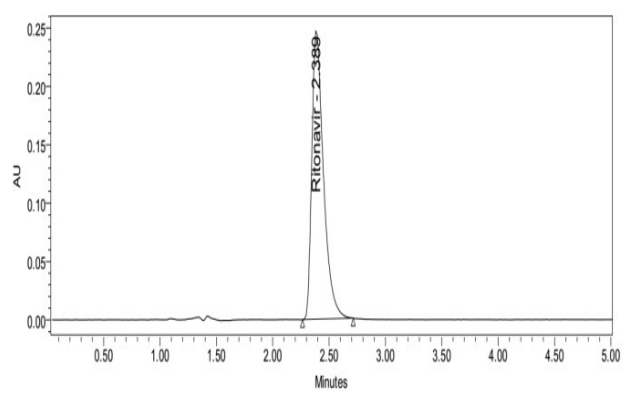

Figure 6: Intermediate precision Chromatogram

Table 6: Linearity Concentration and Response

\begin{tabular}{|c|c|c|}
\hline Linearity Level (\%) & Concentration (ppm) & Area \\
\hline $\mathbf{0}$ & $\mathbf{0}$ & $\mathbf{0}$ \\
\hline $\mathbf{2 5}$ & $\mathbf{2 5}$ & $\mathbf{5 0 0 0 2 2}$ \\
\hline $\mathbf{5 0}$ & $\mathbf{5 0}$ & $\mathbf{1 0 8 0 1 0 7}$ \\
\hline $\mathbf{1 5}$ & $\mathbf{7 5}$ & $\mathbf{1 5 8 4 2 7 4}$ \\
\hline 125 & $\mathbf{1 0 0}$ & $\mathbf{2 0 3 9 8 2 4}$ \\
\hline 150 & $\mathbf{1 2 5}$ & $\mathbf{2 5 2 8 2 9 0}$ \\
\hline
\end{tabular}

Table 7: Accuracy data

\begin{tabular}{|c|c|c|c|}
\hline \multirow{2}{*}{$\%$ Level } & Amount Spiked $(\mu \mathrm{g} / \mathrm{mL})$ & $\begin{array}{c}\text { Amount } \\
\text { recovered }(\mu \mathrm{g} / \mathrm{mL})\end{array}$ & $\begin{array}{c}\text { \% } \\
\text { Mean } \\
\text { Recovery }\end{array}$ \\
\hline \multirow{2}{*}{$50 \%$} & 50 & 49.54 & 99.07 \\
\hline \multirow{3}{*}{$100 \%$} & 50 & 49.62 & 99.23 \\
\cline { 2 - 4 } & 50 & 49.89 & 99.78 \\
\cline { 2 - 4 } & 100 & 100.18 & 100.18 \\
\hline \multirow{3}{*}{$150 \%$} & 100 & 99.63 & 99.63 \\
\cline { 2 - 4 } & 100 & 99.75 & 99.75 \\
\cline { 2 - 4 } & 150 & 148.93 & 99.28 \\
\hline
\end{tabular}

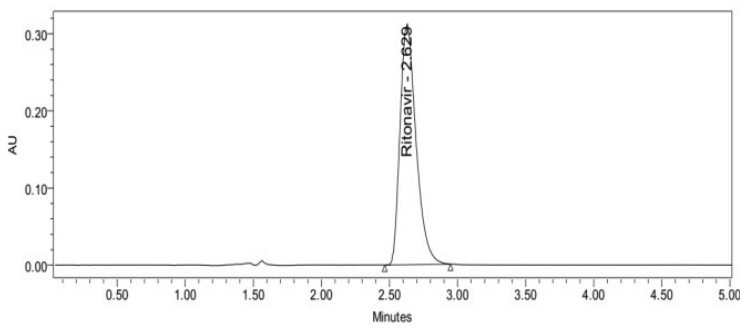

Figure 7: Robustness Chromatogram of Ritonavir

Table 8: Assay of Formulation

\begin{tabular}{|c|c|}
\hline Sample Number & \%Assay \\
\hline 1 & 99.57 \\
\hline 2 & 99.16 \\
\hline 3. & 99.82 \\
\hline 4. & 99.44 \\
\hline 5. & 99.75 \\
\hline 6. & 99.22 \\
\hline AVG & 99.49 \\
\hline \%TDEV & 0.27 \\
\hline
\end{tabular}




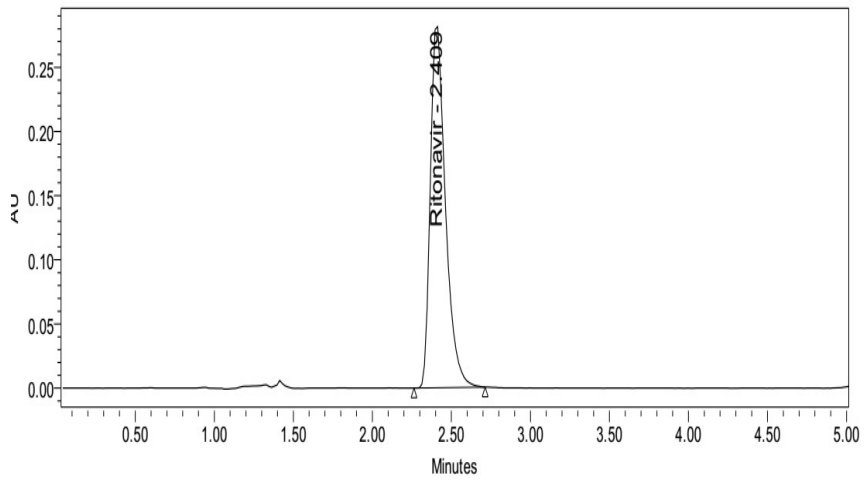

Figure 8: Assay Chromatogram Of Standard

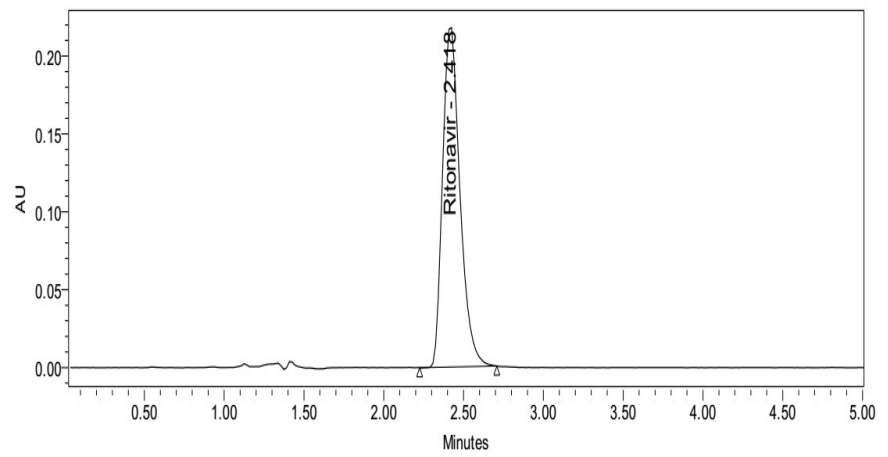

Figure 9: Assay Chromatogram Of Sample

Table 9: Degradation Data of Ritonavir

\begin{tabular}{|c|c|c|c|c|}
\hline S.No. & $\begin{array}{c}\text { Degradation } \\
\text { Condition }\end{array}$ & $\begin{array}{c}\text { \% Drug } \\
\text { Degraded }\end{array}$ & $\begin{array}{c}\text { Purity } \\
\text { Angle }\end{array}$ & Purity Threshold \\
\hline 1 & Acid & 5.79 & 0.794 & 1.033 \\
\hline 2 & Alkali & 4.49 & 2.541 & 3.126 \\
\hline 3 & Oxidation & $\mathbf{8 . 0 5}$ & $\mathbf{0 . 8 9 0}$ & 1.288 \\
\hline 4 & Thermal & 3.73 & 0.916 & 1.276 \\
\hline 5 & UV & 2.34 & 0.152 & 0.365 \\
\hline
\end{tabular}

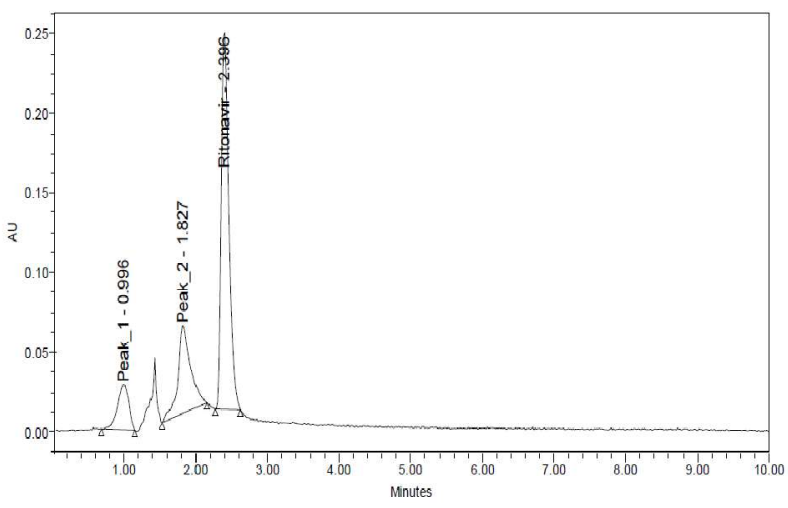

Figure 10: Acid degradation chromatogram 


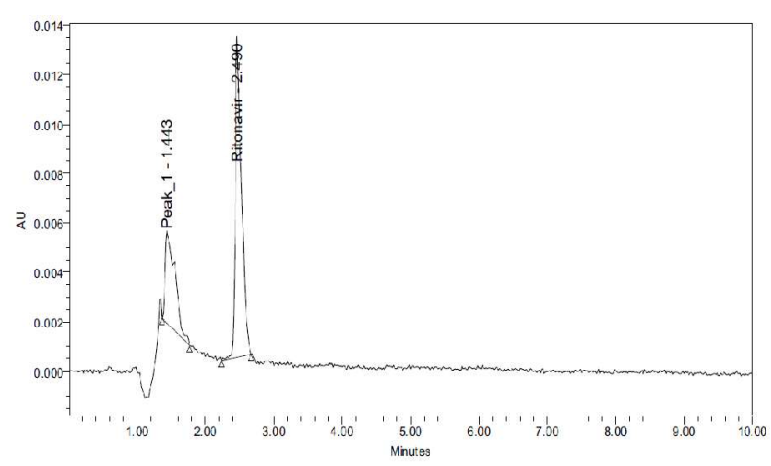

Figure 11: Basedegradation chromatogram

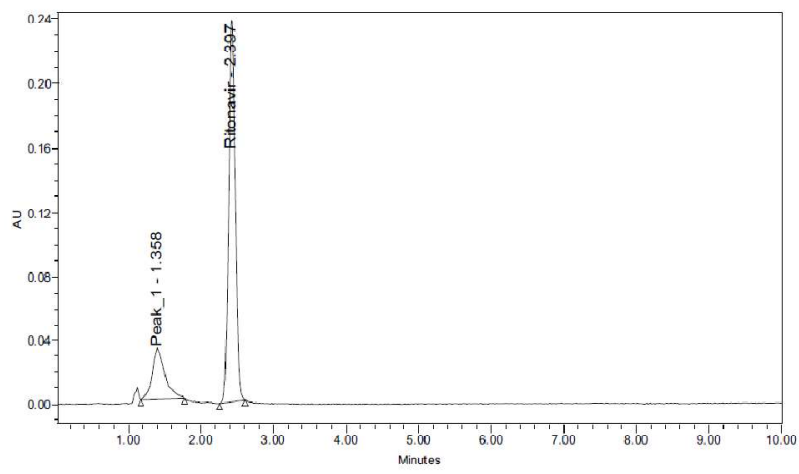

Figure 12: Peroxide degradation chromatogram

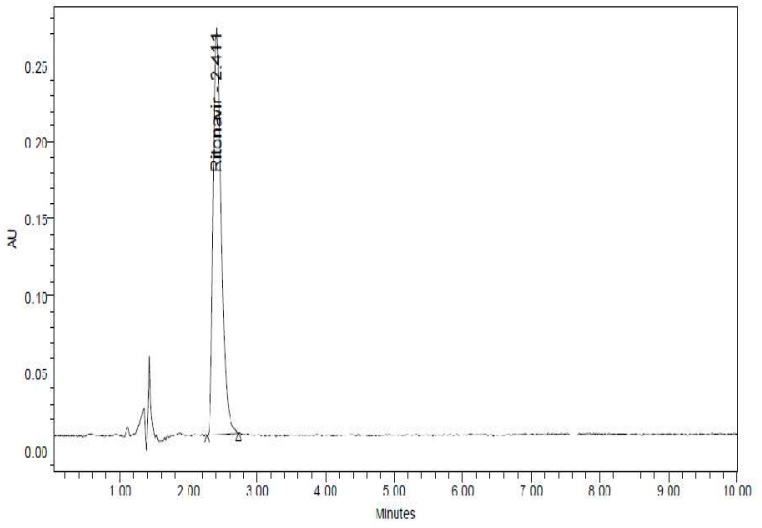

Figure 13: Thermal degradation chromatogram

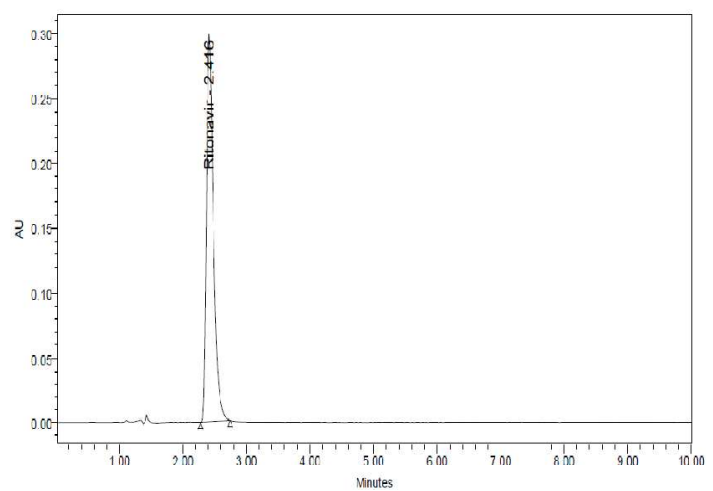

Figure 14: UV degradation chromatogram 


\begin{tabular}{|c|c|}
\hline \multicolumn{2}{|c|}{ Table 10: Summary of validation parameters for the proposed method } \\
\hline Parameters & Ritonavir \\
\hline Linearityrange $(\mu \mathrm{g} / \mathrm{ml})$ & $\mathbf{2 5 - 1 5 0}$ \\
\hline Optimizedwavelength & $239 \mathrm{~nm}$ \\
\hline Retentiontime & $\mathbf{2 . 3 4 5 m i n}$ \\
\hline Regressionequation(Y) & $\mathbf{y}=\mathbf{2 0 4 4 8 x}+\mathbf{1 3 7 6 3}$ \\
\hline Correlationcoefficient $\left(\mathbf{r}^{2}\right)$ & $\mathbf{0 . 9 9 9}$ \\
\hline Precision $(\%$ RSD $)$ & $\mathbf{0 . 3}$ \\
\hline \% Recovery & $\mathbf{9 9 . 4 7 \%}$ \\
\hline Limit ofDetection $(\mu \mathrm{g} / \mathrm{ml})$ & $\mathbf{0 . 5 4}$ \\
\hline LimitofQuantitation $(\mu \mathrm{g} / \mathrm{ml})$ & $\mathbf{1 . 6 5}$ \\
\hline
\end{tabular}

*RSD- Relative standard deviation

\section{CONCLUSION}

Chromatographic conditions used are stationary phase Ascentis $(150 \mathrm{~mm} * 4.6 \mathrm{~mm}$ 2.7 $\mu$.) Mobile phase Acetonitrile: $\mathrm{NaH}_{2} \mathrm{PO}_{4}$ in the ratio of $60: 40$ and flow rate was maintained at $1 \mathrm{ml} / \mathrm{min}$ detection wave length was $239 \mathrm{~nm}$, column temperature was set to $30^{\circ} \mathrm{C}$ and diluent was mobile phase. Conditions were finalized as optimized method. System suitability parameters were studied by injecting the standard six times and results were well under the acceptance criteria. Linearity study was carried out between $25 \%$ to $150 \%$ levels, $\mathrm{R}^{2}$ value was found to be as 0.999 . Precision was found to be 0.3 for repeatability and 0.7 for intermediate precision. LOD and LOQ are $0.54 \mu \mathrm{g} / \mathrm{ml}$ and $1.65 \mu \mathrm{g} / \mathrm{ml}$ respectively. By using above method assay of marketed formulation was carried out $99.49 \%$ was present. Degradation studies of Ritonavir were done, in all conditions purity threshold was more than purity angle and within the acceptable range.

\section{ACKNOWLEDGEMENT}

We would like to thank MYLAN laboratories, Hyderabad for providing gift sample of Ritonavir to carry out this work.

\section{REFERENCES}

[1] Dias CL, Rossi RC, Donato EM, Bergold AM and Froehlich PE. LC Determination of Ritonavir, a HIV Protease Inhibitor, in Soft Gelatin Capsules. J chromatographia 2005; 62:593.

[2] H. H. Willard, L. L. Merrit, J. A. Dean and F. A. Settle. "Instrumental Method of Analysis", 7th edition, CBS Publishers \& Distributors, New Delhi, India, 1986.

[3] International Conference on Harmonization (ICH), Validation of Analytical Procedures: Text on Validation of Analytical Procedures Q2A, 1994.

[4] International Conference on Harmonization (ICH), Validation of 
Analytical Procedures: Methodology Q2B, 1996.

[5] International Conference on Harmonization (ICH), Validation of Analytical Procedures: Text and Methodology Q2 (R1), 2005.

[6] Indian Pharmacopoeia, vol. III, 2007, 1058.

[7] Mohammad H. Abdelhay, Azza A. Gazy, Rasha A. Shaalan* And Heba K. Ashour. Validated Stability-Indicating HPLC and HPTLC Methods for the Determination of Ritonavir in Bulk Powder and in Capsules. Journal of Food and Drug Analysis, Vol. 20, No. 4, 2012, Pages 96s3-973.

[8] Proust V, Toth K, Hulin A, Taburet AM, Gimenez F, Singlas E. Simultaneous High-Performance Liquid Chromatographic determination of the antiretroviral agents' Amprenavi, Nelfinavir, Ritonavir Saquinavir, Delavirdine and Efavirenz in human plasma. Journal of Chromatography $B$ 2000; 742:453-458.

[9] P. D. Sethi. "Quantitative Analysis of Drugs in Pharmaceutical Formulations". 3 rd edition, CBS Publishers \& Distributors, New Delhi, India, 1997.

[10] Richard M, Hoetelmans W, Marjolijn Van Essenberg, Monique Profijt, Pieter L. Meenhorst, Jan W. Mulder, et al. High-Performance Liquid Chromatographic determination of
Ritonavir in human plasma, cerebrospinal fluid and saliva. Journal of Chromatography B: Biomedical Sciences and Applications 1998; 705(1):119-126.

[11] Rebiere Herve, Mazel Bernard, Civade Corinne, Bonnet Pierre-Antoine. Determination of 19 antiretroviral agents in pharmaceuticals or suspected products with two methods using HighPerformance Liquid Chromatography. Journal Of Chromatography B 2007; 850:376-383

[12] Sulebhavikar AV, Pawar UD, Mangoankar KV, Prabhunavelkar ND. HPTLC Method for Simultaneous Determination of Lopinavir and Ritonavir in Capsule Dosage Form. EJournal of Chemistry 2008; 5(4):706712.

[13] Temghare GA, Shetye SS, Joshi SS. Rapid and Sensitive Method for Quantitative Determination of Lopinavir and Ritonavir in Human Plasma by Liquid Chromatography Tandem Mass Specrtometry. E-Journal of Chemistry 2009; 6(1):223-230.

[14] United States Pharmacopoeia 30, National Formulary 25, 2007, 3143.

[15] Usami Yoshiko, Tsuyoshi OK, Naka Masahiko, SagisakaMasafumi, Kaneda Tsuguhiro. A simple HPLC method for simultaneous determination of Lopinavir, Ritonavir and Efavirenz. 
Journal-Chemical And Pharmaceutical

Bulletin 2003; 51:715-718.

[16] Veronica Albert, Pilar Modamio,

Cecilia FL and Eduardo LM.

Determination of Saquinavir and

Ritonavir in human plasma by RP-

HPLC and the analytical error function.

Journal of Pharmaceutical and

Biomedical Analysis 2004; 36(4):835-

840.

[17] Yekkala RS, Ashenafi D, Marien I, Xin

$\mathrm{H}$, Haghedooren E, Hoogmartens $\mathrm{J}$ et

al. Evaluation of an International

Pharmacopoeia method for the analysis

of Ritonavir by Liquid

Chromatography. Journal of

Pharmaceutical And Biomedical

Analysis 2008; 48(3):1050-4. 